慶應義塾大学学術情報リポジトリ

Keio Associated Repository of Academic resouces

\begin{tabular}{|c|l|}
\hline Title & Expressed Emotion and Social Functioning in Chronic Schizophrenia \\
\hline Sub Title & 慢性統合失調症における感情表出と社会機能 \\
\hline Author & 三浦, 勇太(Miura, Yuta) \\
\hline Publisher & 慶應医学会 \\
\hline Publication year & 2005 \\
\hline Jtitle & 慶應医学 (Journal of the Keio Medical Society). Vol.82, No.4 (2005. 12),p.27- \\
\hline JaLC DOI & \\
\hline Abstract & \\
\hline Notes & 号外 \\
\hline Genre & Journal Article \\
\hline URL & $\begin{array}{l}\text { https://koara.lib.keio.ac.jp/xoonips/modules/xoonips/detail.php?koara_id=AN00069296-2005120 } \\
\text { 2-0027 }\end{array}$ \\
\hline
\end{tabular}

慶應義塾大学学術情報リポジトリ(KOARA)に掲載されているコンテンツの著作権は、それぞれの著作者、学会または出版社/発行者に帰属し、その権利は著作権法によって 保護されています。引用にあたっては、著作権法を遵守してご利用ください。

The copyrights of content available on the KeiO Associated Repository of Academic resources (KOARA) belong to the respective authors, academic societies, or publishers/issuers, and these rights are protected by the Japanese Copyright Act. When quoting the content, please follow the Japanese copyright act. 


\title{
Expressed Emotion and Social Functioning in Chronic Schizophrenia
}

\author{
（僈性統合失調症にお付る感情表出と社会機能）
}

\section{三浦勇太}

\section{内容の要旨}

家族の感情表出（Expressed Emotion；以下EE）は患者に対する家族

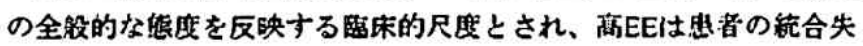
䀦症の再発予測因子になるとされている。EEの离低の成因を解明す るためには、忠者本人の要因や家族貝の要因、さらに文化・社会背景

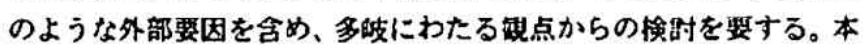

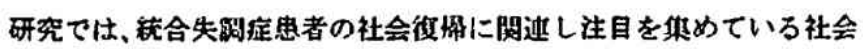
機能に整目し、EEの形成にいかなる影譬を与えているかについて検 即した。

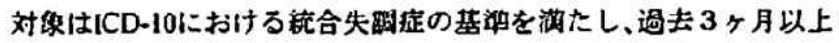
同居家䔩がある44名と、その全家族圆82名である。家族は個別に、日 本部版Social Functioning Scale (SFS) を記入した後、EE伊価用面接で あるFive-Minutes Speech Sample（FMSS）を実施された。また腎者の帮

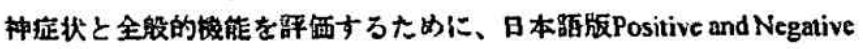
Syndrome Scale (PANSS) と Global Assessment of Functioning Scale

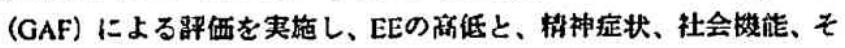

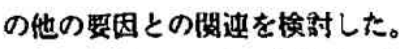

その結梁、52.3\%にあたる23名の患者が晾EE家族貝と同居し、21名 が低EE家族貝とのみ同居していた。融EE群と低EE群では、击者の性

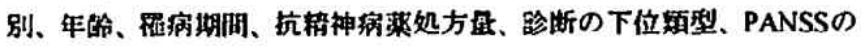
下位项目、GAFスコアにおいて有意差はなかった。高EE群と低EE群間 では、点数が品いほと社会機能がより高いことを示すSFSの 2つの下 位项目 (社会的引きこもり、自立レヘル（能力》) と合胡点のそれぞれ において、低EE群の方が有意に樆い点数を示した。部EE群における低 EE家族只と低EE徉の家族貝との比䑤では、社会的引きこもり、対人機 能、自立レペル (能力) 項目において、低EE些の方が有总に融かった。 得られた結果の因子分析では 4つの因子が潾かか、第 2 因子がEEと SFS合咕点によって跘明され、两EEがSFSスコア低值と関連していた。

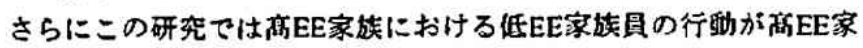
族員のそれに類似していることが胃出された。徒ってより勃果的なり ハヒリテーションのためには离EE家族における低EE家族貝も繶合失

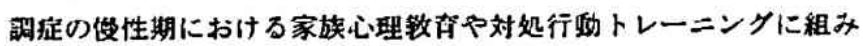
入れられる必要があることを示唆するものである。

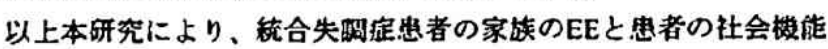
水湖には双方向性に因果関俰を持つことが明らかになった。また愠性 統合失閶店患者の家族員はおそらく患者の日常の社会掞能を注視し ており、患者の社会機能のレベルは家族のEEプロフィールに影譬し ていることが示惨された。

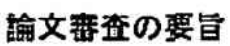

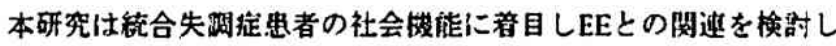
たものである。対象は同居家族がある44名と、全家族82名であつ た。SFSが家族により砰価され、FMSSおよびPANSSとGAFも実施さ れた。23名 $(52.3 \%)$ の贯者が满EE 家族と、21名が低EE家族とのみ 同居していた。商EE眻と低EE群閑では、SFSの下位項目（社会的引 きこもり、自立レベル（能力)）と合勒点において、低EE徉の方が 有意に能い点数を示した。高EE徉における低EE家族と低EE徉の家 族との比较では、社会的引きこもり、対人能能、自立レベル（能

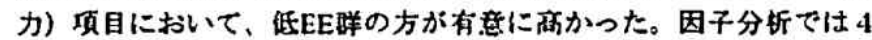

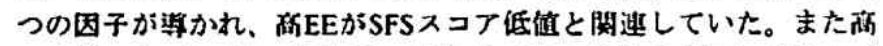
EE家族における低EE家族頁の行動は、高EE家族のそれに期似して いた。

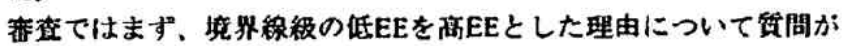
なされた。先行研究では境界稳的の低EEを面EEとした场合、より予 後の予测性が高まることが指畝されており、本研究もそれに従った

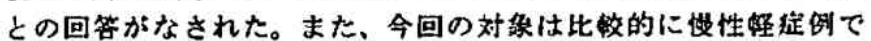
あった可能性もあるが、この㘬合にもEEが再発可能性に影整を与え

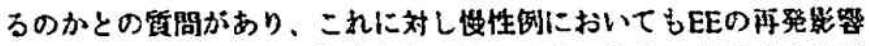
性が認められていると回答された。絔いて的EEと低EEを形成する要 因についての質間がなされた。病哳からの家族侧の要因についての 検时は十分にはなされていないと回答があり、それに対し、冢族の 相互関俰性や役剖の通いも含めた挨討を今後行うへきとの指摘が

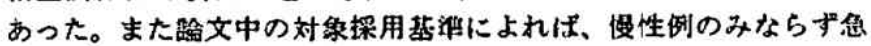

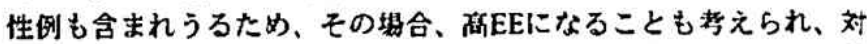

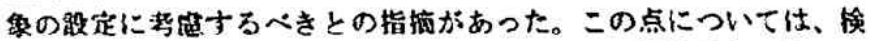

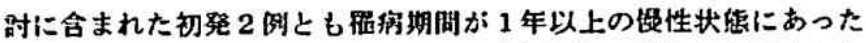
と回答された。今回の結果ではEEと社会機能の阅連が础路された

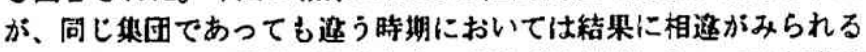
こともあるかとの蚠閭がなされた。例えば急性期においては幻党妄 想なとの目立つ梢神位状に対して家族の批判が强まることは予热さ れ、また扇期によって家族の注息の対象が变わることも宩えられる ことから、同一集団であっても結果に相连がみられる可能性が高い

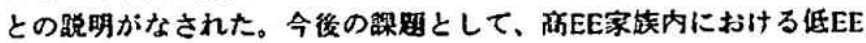
家族目に黛点をあてる研究においては、同居家族が 1 名の城合には これを検时対象から除外するへきこと、砰価方法としてのSFSの内 部梅造について一居の検䣄が必呟であることが指脑された。

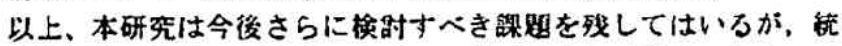

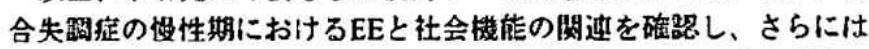
活EE家族冒と同居する低EE家族貝一の監本的介入の必要性を明らか にした点で、臨床的に価值ある研究と話価された。

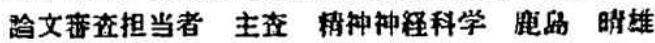

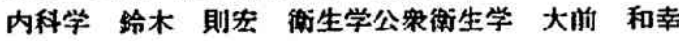

医旅政策 - 管理学 池上 值己

学力砤跑担当者 : 北呙 政楖、鉿木 則宏

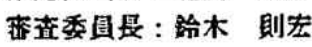

